\title{
First observational record of Siberian weasel Mustela sibirica Pallas, 1773 in Dhorpatan Hunting Reserve, Nepal
}

\author{
Hari Basnet*1(D) | Deepa LamaiD | Manju Shree Thakur² ${ }^{\text {ID }}$ | Prakriti Rajbhandari² I Rejina
}

\author{
Bista $^{2}$ (D) | Rona Vaidya² ${ }^{\text {(D) }}$ Prakash Chandra Aryal2 ${ }^{2}$
}

${ }^{1}$ Nepalese Ornithological Union, Chabahil, Kathmandu, Nepal

${ }^{2}$ GoldenGate International College, Wisdom Tower, Kathmandu, Nepal

* Correspondence: haribasnet88@gmail.com

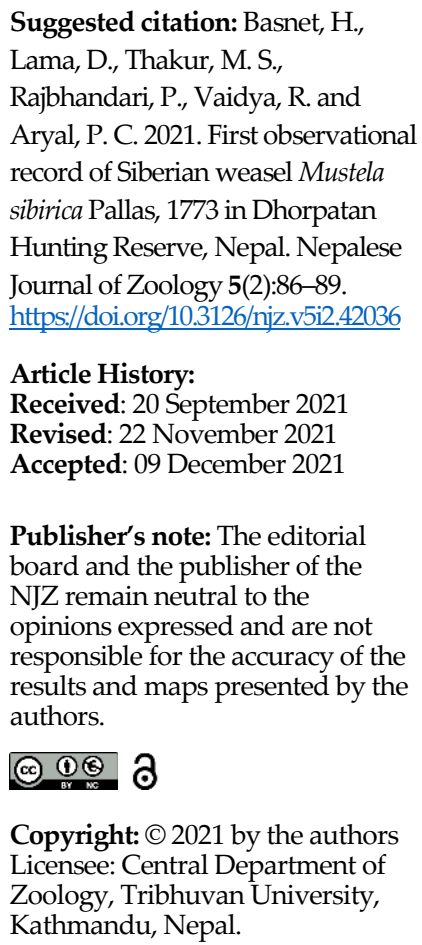

\begin{abstract}
Siberian weasel Mustela sibirica Pallas, 1773 is one of the least known small carnivores in Nepal. Only a few authenticated localities of Siberian weasel are known to exist in Nepal. In March 2021, a week-long field trip to the Dhorpatan Valley documented the first confirmed record of Siberian weasel in Dhorpatan Hunting Reserve in Western Nepal.
\end{abstract}

Keywords: Dhorpatan Valley, Mustelidae, Mammals, Opportunistic record, Carnivores

\section{I Introduction}

Siberian weasel Mustela sibirica Pallas, 1773 is one of the six weasel species (Mountain weasel $M$. altaica, stoat $M$. erminea, yellowbellied weasel $M$. kathiah, stripe-backed weasel M. strigidorsa, and steppe polecat $M$. eversmanii) that are reported to occur in Nepal (Jnawali et al. 2011; Chetri et al. 2014). However, occurrence of striped-backed weasel is not confirmed in Nepal (Abramov et al. 2008; Thapa 2014) whereas, stoat has been excluded from the Nepal's list (Mitchell 1975; Thapa 2014; Reid 2016). Siberian weasel is listed as Least Concern on the IUCN Red List of Threatened Species (Abramov et al. 2016). Jnawali et al. (2011) categorized the species as Least Concern in Nepal based on its wide distribution having a large population and lack of any identified major threats. Siberian weasel inhabits a wide range of habitats, including dense forests, primary and secondary deciduous, coniferous and mixed forests, rhododendron forests, river valleys, and human settlements (Jnawali et al. 2011; Menon 2014). The main diet comprises of small mammals such as voles, squirrels, mice, and pikas, as well as amphibians, fish, and carrion (Abramov et al. 2016). It is reported to occur across Nepal with specific records from Annapurna Conservation Area (ACA), Shey Phoksundo National Park, Rara National Park, Sagarmatha National Park (Jnawali et al. 2011), Makalu Barun National Park (Jnawali et al. 2011; Ghimirey et al. 2014), Manaslu CA (Katuwal et al. 2013), Apinampa Conservation Area (Yadav et al. 2018). Outside the protected areas, the species has been reported from Humla and Mugu districts (Ghimirey et al. 2014; Yadav et al. 2018). However, to date, there has been no sighting and photographic record of this species in Dhorpatan Hunting Reserve (DHR) prior to the 


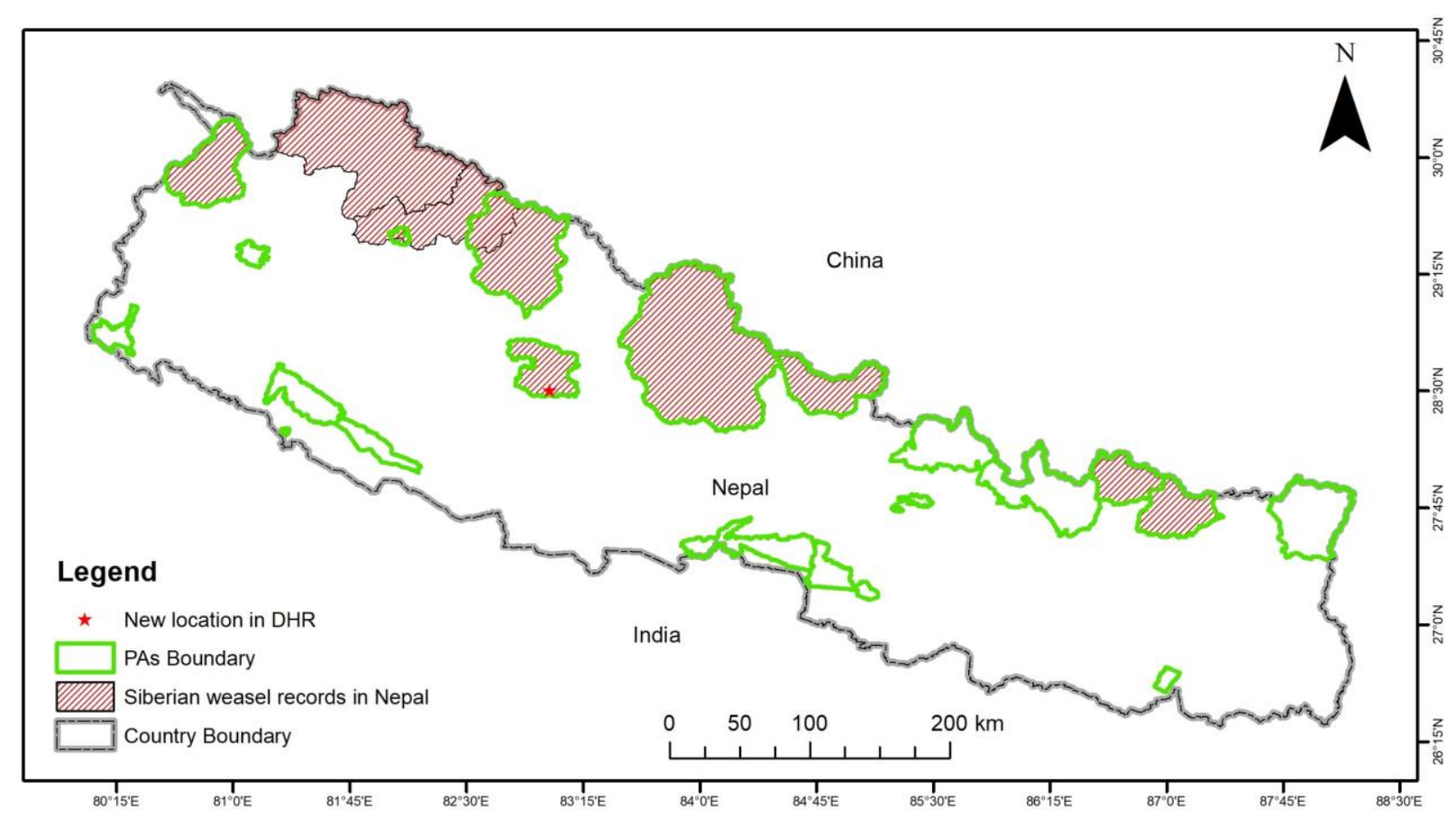

Figure 1. Siberian weasel distribution in Nepal. Red star represents the location of the species observation in the Dhorpatan Hunting Reserve.

present records. Thus, this note reports the first sighting of the Siberian weasel from Dhorpatan Valley within the DHR.

\section{2 | Materials and methods}

\subsection{Study area}

This study was conducted in the Dhorpatan valley, which is located in south-east corner of DHR. DHR is known for its regulated trophy hunting of the blue sheep Pseudois nayaur and Himalayan tahr Hemitragus jemlahicus. The major occupations of the locals of Dhorpatan Valley are potato cultivation and livestock rearing. The human population of the Dhorpatan Valley has expanded since the valley's roadways were connected. This draws a significant number of visitors who spend a few days traveling around the valley, affecting Dhorpatan Valley's biodiversity.

\section{2 | Field survey}

The field survey was conducted in the last week of March to access the bird diversity in the Dhorpatan Valley. Three habitat types were chosen in which

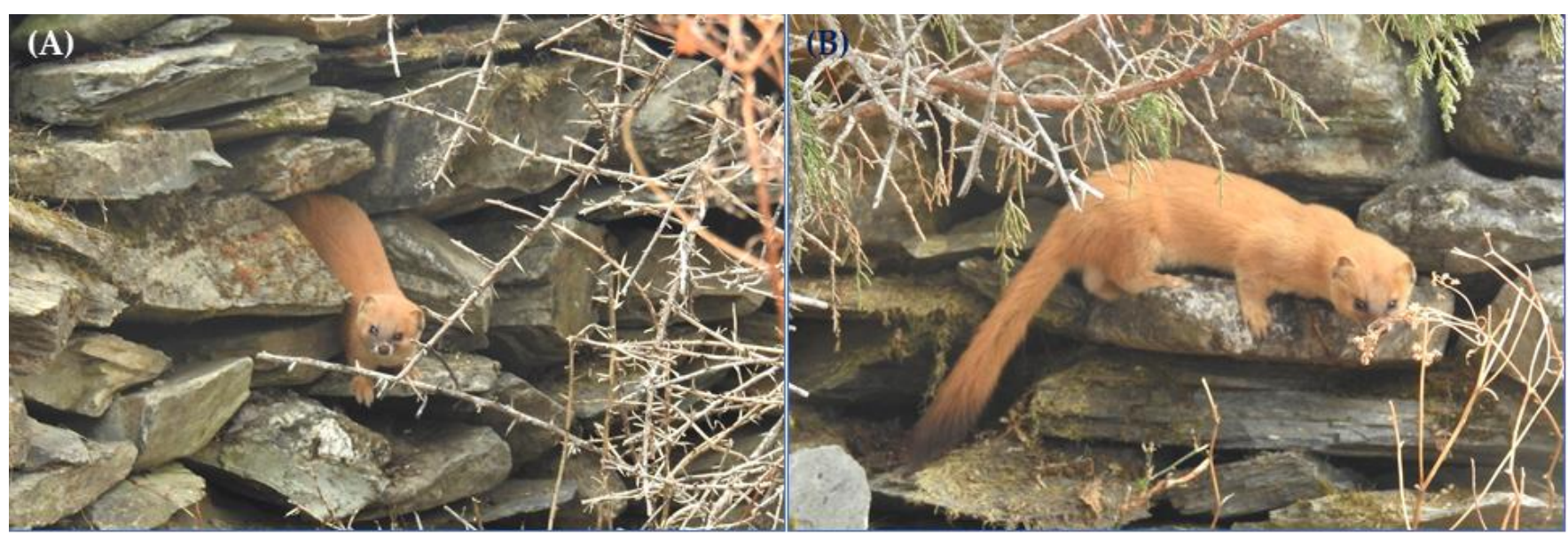

Figure 2. A, Siberian weasel coming out of stone crevices; B, Clear black tip, uniform body color, dark chocolate coloration on the snout are identifiable characteristics of the species (Photo by: Hari Basnet). 
three transects each of one kilometer length was overlaid. Aside from bird surveys, opportunistic encounters with any other species were taken into account. The field scanning was done with an Asika $8 \times 42$ binoculars and photograph was taken using Nikon P900 with occurrence data recorded using Garmin eTrex 10 GPS.

\section{3 | Results}

On 29 March 2021 at 09:34 AM, we were counting birds in the Syalpakhe area $\left(28.5048^{\circ} \mathrm{E}, 83.0383^{\circ} \mathrm{N}\right.$, $2,956 \mathrm{~m}$ asl), around $2.5 \mathrm{~km}$ North-West of the DHR headquarter in Dhorpatan Valley (Fig. 1). We were stopped by fast movements of the two Royle's pika Ochotona roylei on stone fence at the edge of farmland. At first glance, we noticed a weasel entering the stone crevices, causing the pikas to flee (Fig. 2A). The weasel has uniform light orange body color with light pale coloration in its chest, white flecks in the muzzle, dark chocolate patch from its snout to eyes and clear black tail tip suggesting the species to be Siberian weasel (Fig. 2B). The morphological characteristics is similar as described by the Menon (2014). We stood for about two minutes, and the weasel entered the crevices four times, chasing the pikas without being bothered by our presence, although, we were less than 10 meters away.

The surrounding area was shrubby with thorny bushes and juniper saplings, a few scattered houses and farmland surrounded by stone fences to keep out wild animals, particularly wild boar Sus scrofa and domestic cattle.

\section{4 | Discussion}

Dhorpatan Valley is the main entry point to the hunting reserve headquarter and the most accessible area to researchers in DHR. But previous scientific literature and other study documents from the reserve have not reported its presence, implying that current species record is the first one from the reserve. Furthermore, the species is rare in the valley, as the authors never saw the species despite having visited the area each year for research and a week's long field trips.
The vegetation in the valley is characterized by Abies spectabilis, Rhododendron spp., Toona spp., Picea spp., Quercus spp., Acer spp. and Cupressus spp. (Lelliot 1981). Seasonal snowfall occurs during winter and maximum precipitation occurs in July and August (Singh et al. 2011; Basnet 2015). In the valley, dry agriculture practices, widespread grazing of horses and cattle with seasonal concentrations during spring and autumn are prominent features. Valley floor is dominated by grazing wetland and fringe area has settlements with agriculture field. The agriculture fields are protected by raising stone walls to prevent crop raiding by cattle and wildlife. These stone fences are beneficial to the pika population. Pikas were sighted in several location along the trails in the valley and thus it is likely that few more Siberian weasels might exist if a species-focused survey is conducted at an appropriate time.

Only a few authenticated localities of Siberian weasel are known to exist in Nepal (Ghimirey \& Acharya 2012; Ghimirey et al. 2014), indicating its rarity. Its conservation status in Nepal has to be reevaluated. Furthermore, the species necessitates more attention, including behavioral and ecological study. Furthermore, locals have limited conservation knowledge as they were involved in hunting and snaring of threatened species like cheer pheasant (Catreus wallichii) in the valley (Basnet et al. 2020). As a result, increasing local conservation knowledge could help to ensure the survival of this rare species in the valley, which would then aid in ecologically based rodent management because the species predates pikas and other rodents in the valley that raid agriculture crops like potato and wheat.

\section{5 | Conclusions}

Our survey records the first confirmation record of Siberian Weasel from Dhorpatan Hunting Reserve. However, a species-specific survey of the Siberian Weasel would be beneficial in understanding the species' ecological and behavioural information, which is scarce in Nepal. 


\section{Acknowledgements}

We thank Mr. Sanjan Thapa for the species confirmation. We also thank M.Sc. environmental science students (Batch: 2075 BS) and GoldenGate International College, Kathmandu for supporting the field visit.

\section{Conflicts of interest}

Authors declare no conflict of interest.

\section{Authors' contributions}

All the authors collected the data and reviewed the literature. Basnet, H. and Aryal, P. C. wrote the manuscript and all the authors provided suggestions and feedback and gave final approval for publication.

\section{ORCID}

Hari Basnet: https://orcid.org/0000-0003-4179-8074

Deepa Lama: https://orcid.org/0000-0002-2447-9517

Manju Shree Thakur: https://orcid.org/0000-0001-7942-6968

Prakriti Rajbhandari: https://orcid.org/0000-0003-0349-2402

Rejina Bista: https://orcid.org/0000-0002-2821-4858

Rona Vaidya: https://orcid.org/0000-0002-4830-341X

Prakash C. Aryal: https://orcid.org/0000-0003-3023-1080

\section{References}

Abramov, A. V., Duckworth, J. W., Choudhury, A., Chutipong, W., Timmins, R. J., Ghimirey, Y. et al. 2016. Mustela sibirica. The IUCN Red List of Threatened Species 2016.

http://dx.doi.org/10.2305/IUCN.UK.2016-1.RLTS.T41659A45214744.en. Downloaded on 08 Sept 2021.

Abramov, A. V., Duckworth, J. W., Wang, Y. and Roberton, S. I. 2008. The stripe-backed weasel Mustela strigidorsa: taxonomy, ecology, distribution and status. Mammal Review 48:247-266.

Basnet, H. 2015. Population status, occupancy and distribution modelling of cheer pheasant Catreus wallichii in Dhorpatan Hunting Reserve, Nepal. A master thesis submitted to Central Department of Zoology, Tribhuvan University, Kirtipur, Kathmandu

Basnet, H., Thapa, T. B., Subedi, P. and Katuwal, H. B. 2020. Decline of the Cheer Pheasant Catreus wallichii in Dhorpatan Hunting Reserve, Nepal. Forktail, 36:114116
Chetri, M., Odden M., McCarthy T. and Wegge P. 2014. First record of steppe polecat Mustela eversmanii in Nepal. Small Carnivore Conservation 51:79-81.

Ghimirey, Y. and Acharya, R. 2012. Records of Siberian weasel Mustela sibirica and yellow-bellied weasel Mustela kathiah from Makalu-Barun National Park, Nepal. Small Carnivore Conservation 47:68-69.

Ghimirey, Y., Acharya, R., Chaudhary, A. and Prajapati, A. 2014. Observations of mountain weasel Mustela altaica and Siberian weasel Mustela sibirica in Nepal. Small Carnivore Conservation 50:64-65.

Jnawali, S. R., Baral, H. S., Lee, S., Acharya, K. P., Upadhyay, G. P., Pandey, M., et al. (compilers) 2011. The status of Nepal mammals: the national red list series. Department of National Parks and Wildlife Conservation, Kathmandu, Nepal.

Katuwal, H. B., Khanal, B., Basnet, K., Rai, B., Devkota, S., Rai, S. K., et al. 2013. The mammalian fauna from the Central Himalaya, Nepal. Asian Journal of Conservation Biology 2:21-29.

Lelliott, A. D. 1981. Survey of cheer pheasant near Dhorpatan west Nepal 1981. In: Savage, C. D. W. and Ridley, M. W. (Eds.) Pheasants in Asia 1982. WPA, Reading UK. pp 58-61.

Menon, V. 2014. Indian mammals-A field guide. Hachette book publishing India Pvt. Ltd, Gurgaon, India

Mitchell, R. M. 1975. A checklist of Nepalese mammals (excluding bats). Säugetier Kundliche Mitte-ilungen 23:152-157.

Reid, F., Helgen, K. and Kranz, A. 2016. Mustela erminea. The IUCN Red List of Threatened Species 2016: e.T29674A45203335.

https://dx.doi.org/10.2305/IUCN.UK.2016-1.RLTS.T29674A45203335.en.

Singh, P. B., Subedi, P., Garson, P. J. and Poudyal, L. 2011. Status, habitat use and threats of cheer pheasant Catreus wallichii in and around Dhorpatan Hunting Reserve, Nepal. International Journal of Galliformes Conservation 2:22-30.

Thapa S. 2014. A Checklist of mammals of Nepal. Journal of Threatened Taxa 6:6061-6072.

Yadav, K., Ghimirey, Y., Ghimire, S. K., Prajapati, A., and Acharya, R. 2018. Observations of Siberian weasel Mustela sibirica in Api-Nampa Conservation Area, Darchula district and Humla district, Nepal. Small Carnivore Conservation 57:14-19. 